\title{
Daily variation in body mass and thermoregulation in male Hwamei (Garrulax canorus) at different seasons
}

\author{
Lidan Zhao ${ }^{1}$, Runmei Wang ${ }^{1}$, Yunan $\mathrm{Wu}^{1}$, Mengsi Wu' ${ }^{1}$, Weihong Zheng ${ }^{1,2}$ and Jinsong Liu ${ }^{1,2^{*}}$
}

\begin{abstract}
Background: Acclimatization to winter conditions is an essential prerequisite for survival of small passerines of the northern temperate zone. In the present study, we measured diurnal variations in body mass, body temperature and basal metabolic rate (BMR) for seasonally acclimatized Hwameis (Garrulax canorus).

Methods: Body mass was determined with a Sartorius balance. Metabolic rates of Hwameis were measured with an open-circuit respirometry system.

Results: Body masses varied with time of day and were higher in daytime for Hwameis in both summer and winter, and body masses in winter were higher compared to that in summer. Body temperatures of Hwameis were higher in daytime, and the summer acclimatized birds had significantly higher body temperatures compared to the winter acclimatized birds. BMRs of Hwameis were significantly higher during the daytime compared to the nighttime of the daily cycle in both summer and winter, and Hwameis in winter had significantly higher BMRs than that in summer.

Conclusions: This result showed that Hwameis rely mostly on metabolic capacity to maintain their body temperature in cold weathers, and Hwameis exhibited daily and seasonal flexibility in morphology and physiology which is important under changing environmental conditions.
\end{abstract}

Keywords: Hwamei (Garrulax canorus), Body mass, Body temperature, Diurnal rhythm, Metabolic rate

\section{Background}

Phenotypic plasticity, the capacity to modulate structural and functional characteristics in response to varying environmental challenges, is an important fundamental trait of many organisms and has been paid much attention in recent years (Auld et al. 2010; Beldade et al. 2011). Many of these studies focused on the plasticity within the lifespan of an individual, a form of phenotypic plasticity that has been termed "phenotypic flexibility" (Piersma and Drent 2003). Phenotypic flexibility refers to phenotypic changes that are reversible, temporary and repeatable, such as acclimation and acclimatization (Piersma and Drent 2003; Starck 2009; Liknes and Swanson 2011). The study on phenotypic plasticity has become a

\footnotetext{
* Correspondence: ljs@wzu.edu.cn

${ }^{1}$ School of Life and Environmental Sciences, Wenzhou University, Wenzhou 325035, China

${ }^{2}$ Key Laboratory of Water Environment and Marine Biological Resources Protection in Zhejiang Province, Wenzhou University, Wenzhou 325035, China
}

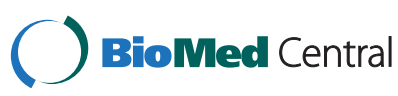

(C) 2015 Zhao et al.; licensee BioMed Central. This is an Open Access article distributed under the terms of the Creative Commons Attribution License (http://creativecommons.org/licenses/by/4.0), which permits unrestricted use, distribution, and reproduction in any medium, provided the original work is properly credited. The Creative Commons Public Domain Dedication waiver (http://creativecommons.org/publicdomain/zero/1.0/) applies to the data made available in this article unless otherwise stated. central topic in evolutionary ecology and resident endothermic animals in temperate climates provide for natural experiments in phenotypic flexibility (Liknes and Swanson 2011; Wu et al. 2014).

In birds, body mass is an important indicator reflecting their level of energy balance (Doucette and Geiser 2008). Many birds display phenotypic flexibility in maintaining energy requirements, capable of up and down body mass regulation over a period of time in response to thermal acclimation (Vézina et al. 2006; Zheng et al. 2013a), season (Zheng et al. 2008a, 2008b, 2014a; Petit et al. 2014), elevation (Lindsay et al. 2009) and latitude (Wikelski et al. 2003; Zheng et al. 2013b, 2014b). Thermoregulatory responses are known to differ seasonally in birds, often dependent on the environment and region in which they reside (Bush et al. 2008; Zheng et al. 2008a, 2014a). Non-migratory birds at temperate latitudes undergo drastic seasonal variation in day length, temperature and food availability (Yuni and Rose 
2005; Wiersma et al. 2007). They cope with winter by seasonal metabolic adjustments, such as winter increases in both basal (BMR, minimum metabolic rate) and summit $\left(M_{\text {sum }}\right.$, maximal thermoregulatory metabolic rate) metabolic rates in seasonally cold climates (Swanson 1990, 2010; Swanson et al. 2014; Zheng et al. 2014a). BMR refers to the energy expenditure of an animal at rest (i.e., thermoneutrality) during the inactive phase of the day, when the animal is not processing food, moulting, or reproducing (Zheng et al. 2008a; McNab 2009; Swanson 2010). The increase in winter BMR is likely the result from higher support costs for thermogenic tissues (Swanson 2010). Many small winter-active birds inhabiting temperate latitudes in the northern hemisphere increase their BMR in winter compared to that in summer (Bush et al. 2008; Swanson et al. 2014; Zheng et al. 2014a). Birds also show a daily variation in body mass and metabolic rate, with maximum body mass and metabolic rate occurring during the day, with minimum body mass and metabolic rate occurring at night (Arens and Cooper 2005; Polo and Carrascal 2008; Lindsay et al. 2009). For example, Pohl and West (1973) showed that the body mass and BMR of common redpolls (Acanthis flammea) were significantly higher during the daytime compared to the night of a daily cycle in both summer and winter. Arens and Cooper (2005) also found that the BMR of house sparrows (Passer domesticus) between daytime and nighttime in winter and summer was significant. These results suggest that the ability to elevate BMR is an important component of winter acclimatization, important to winter survival (Swanson 2010; Burns et al. 2013; Zheng et al. 2014a). As well, the nocturnal reductions in both body mass and metabolic rate in small diurnal birds are known to be greater in periods of food shortage or exposure to cold stress conditions, commonly used to conserve energy (Polo and Carrascal 2008; Chamane and Downs 2009; Lindsay et al. 2009).

The Hwamei (Garrulax canorus) (Timaliidae) is an endemic Asian species found in central and southern China including Taiwan and northern Vietnam ( $\mathrm{Li}$ et al. 2006; MacKinnon and Phillipps 2000). Within its natural range, the Hwamei preferentially inhabits scrubland, open woodland, secondary forest, parks and gardens up to $1800 \mathrm{~m}$ above sea level (Zheng and Zhang 2002). Due to the elaborate song of males, the Hwamei is one of the most popular cage birds among the global Chinese community (Li et al. 2006). The Hwamei is omnivorous and mainly feeds on arthropods (insects and spiders) in the breeding season, but also eats plants (fruits and seeds) in autumn and winter (Zheng and Zhang 2002). The reported ecological and physiological properties of the Hwamei show relatively lower BMR than predicted for their body from allometric equations (Aschoff and Pohl 1970; McKechnie and Wolf 2004), high body temperature, a narrow thermal neutral zone (TNZ) and high metabolic water production/evaporative water loss (MWP/EWL) (Xia et al. 2013). These characteristics suggest that this species is adapted to warm, mesic climates, where metabolic thermogenesis and water conservation do not constitute strong selective pressures (Liu et al. 2005; Xia et al. 2013). Hwameis also show seasonal metabolic acclimatization similar to other temperate wintering passerines, associated with a significant increase in oxygen consumption $(20 \%)$ in the winter relative to the summer. This improved cold tolerance is mainly associated with a significant increase in BMR in winter birds compared to summer birds (Wu et al. 2015). We selected this species because there is little available information on the ecological physiology of the Hwamei and the Timaliidae in general (Xia et al. 2013; Wu et al. 2015). The present study follows up on previous work and investigates daily and seasonal changes in body mass and metabolic performance of the Hwamei in southeastern China. Our objectives were to investigate the daily and seasonal differences in body mass, body temperature and metabolism in seasonally acclimatized Hwameis. Therefore, we measured the change in body mass, body temperature and metabolic rate of Hwameis during both daytime and nighttime in summer and winter. We hypothesize that the Hwamei would cope with winter temperatures by increasing its body mass and metabolic rate, both of which enhance the capacity to survive in cold environments. We also predict that the Hwamei would have lower body mass, body temperature and metabolic rate at nighttime, all of which reduce nocturnal energy expenditures. In Wenzhou, the mean annual temperature is $18^{\circ} \mathrm{C}$ and mean daily maximum temperatures range from $39^{\circ} \mathrm{C}$ in July to $8^{\circ} \mathrm{C}$ in January, with mean daily minima from $28^{\circ} \mathrm{C}$ in July to $3^{\circ} \mathrm{C}$ in January. Mean ambient temperature for Wenzhou ranged from $7.7 \pm 0.5^{\circ} \mathrm{C}$ in winter (between January and February 2011) to $29.4 \pm 0.2^{\circ} \mathrm{C}$ in summer (between July and August 2011). Daily minimum and maximum ambient temperatures varied greatly, ranging from $4.1 \pm 0.4^{\circ} \mathrm{C}$ to $11.3 \pm 0.5^{\circ} \mathrm{C}$ in winter to $25.5 \pm$ $0.1^{\circ} \mathrm{C}$ to $33.2 .0 \pm 0.2^{\circ} \mathrm{C}$ in summer.

\section{Methods}

Our study was carried out in Wenzhou City, Zhejiang Province, China, which has a warm-temperate climate with an average annual rainfall of $1700 \mathrm{~mm}$ spread over the year and slightly more precipitation during the winter and spring (Zheng et al. 2008a, 2014a).

\section{Animals}

Sixteen Hwameis (9 $\hat{\partial}$ in winter and $7 \hat{\sigma}$ in summer), used in our experiments, were live-trapped in forest regions between winter (from January to February) and summer (from July to August) 2011. Body mass to the 
nearest $0.1 \mathrm{~g}$ was determined immediately upon capture with an electronic balance (Sartorius BT25S, Germany). The birds were transported to the laboratory and caged for 1 or $2 \mathrm{~d}\left(50 \times 30 \times 20 \mathrm{~cm}^{3}\right)$ outdoors under natural photoperiods and temperatures before measurements. The Hwameis were maintained on commercial Hwamei pellets, consisting of $20 \%$ crude protein, $6 \%$ crude fat, $4 \%$ crude fibre, $1 \%$ calcium, $0.5 \%$ lysine and $0.5 \%$ methionine + cystine, obtained from the Jiangsu Xie Tong Bioengineering Co., China. Food and water were supplied ad libitum. All animal procedures were licensed under the Institutional Animal Care and Use Committee of the Institute of Zoology, Chinese Academy of Sciences.

\section{Ambient temperature measurements}

Ambient temperature for Wenzhou $\left(27^{\circ} 29^{\prime} \mathrm{N}, 120^{\circ} 51^{\prime} \mathrm{E}\right.$, $14 \mathrm{~m}$ in elevation) was obtained from the Wenzhou Bureau of Meteorology for the winter of 2011 (from January to February) and the summer (from July to August).

\section{Body temperature measurements}

We measured the body temperature of each bird using a lubricated thermocouple. This was inserted cloacally to a depth at which a slight withdrawal did not result in a change in the reading $(1-2 \mathrm{~cm})$. Thermocouple outputs were digitized using a thermocouple meter (Beijing Normal University Instrument Co., China). All measurements were taken hourly for a period of 24 hours.

\section{Metabolic trials}

We measured metabolic rates of Hwameis with an opencircuit respirometry (AEI Technologies Model S-3A/I, USA). Metabolic chambers were constructed from $1.5 \mathrm{~L}$ plastic metabolic chambers, in which a perch was provided (Smit and McKechnie 2010). The chamber temperature was kept constant by placing the apparatus in a temperature-controlled cabinet (Artificial Climatic Engine BIC-300, China) capable of regulating temperature to $\pm 0.5^{\circ} \mathrm{C}$ of the set value. We scrubbed water vapor and $\mathrm{CO}_{2}$ using a silica gel/soda lime/silica column before passing through the oxygen analyzer. The amount of oxygen in the exiting gas from the metabolic chamber was measured using an oxygen sensor (AEI Technologies N-22 M, USA). When measuring metabolic rates, we maintained flow rates of exiting gas at $300 \mathrm{~mL} / \mathrm{min}$ in the summer and at $600 \mathrm{~mL} / \mathrm{min}$ in the winter with a flow control system (AEI Technologies R-1, USA) in order to maintain a fractional concentration of $\mathrm{O}_{2}$ in the respirometry chambers of approximately $20 \%$, calibrated to $\pm 1 \%$ accuracy with a general purpose thermal mass flow-meter (TSI 4100 Series, USA) (McNab 2006). Consumption rates of oxygen were measured at $30 \pm 0.5^{\circ} \mathrm{C}$, which is near the thermal neutral zone of Hwameis (Liu et al. 2005; Xia et al. 2013). We obtained baseline $\mathrm{O}_{2}$ concentrations before and after each test (Li et al. 2010). All measurements of gas exchange were obtained during the restphase in darkened chambers and from individual birds that could reasonably be expected to be post absorptive. Food was removed $4 \mathrm{~h}$ before each measurement period to minimize the heat increment associated with feeding. We ensured that the birds were perched calmly in the chambers and then started recording oxygen consumption data at least $1 \mathrm{~h}$ after the rest-phase. As a rule, each animal was in the metabolic chamber for at least $2 \mathrm{~h}$. From these data, we calculated 5 min running means of instantaneous oxygen consumption over the entire test period using the $2^{\text {nd }}$ equation of Hill (1972) and considered the lowest 5 min mean oxygen consumption over the test period as the BMR (Smit and McKechnie 2010). We expressed all measurements of oxygen consumption as $\mathrm{mL} \mathrm{O}_{2} \cdot \mathrm{h}^{-1}$ and corrected to STPD conditions (Schmidt-Nielsen 1997). All measurements were made daily from 8:00 to 16:00, 16:00 to $0: 00$ and 0:00 to $8: 00$.

\section{Statistics}

The data were analyzed using the SPSS statistical package (Windows, version 12.0). The diurnal rhythm of body mass and body temperature between winter and summer in Hwameis were analyzed using repeated measures ANOVA (RM ANOVA). The difference in the diurnal rhythm of metabolic thermogenesis between winter and summer in Hwameis were analyzed using repeated measures ANCOVA (RM ANCOVA) with body mass as the covariate. Where appropriate, multiple posthoc comparisons were made using least significant differences (LSD). The differences in body mass and body temperature between winter and summer groups or day and night groups were analyzed by two-way ANOVA. The differences in metabolic rates between winter and summer groups or day and night groups were analyzed by two-way ANCONA with body mass again as the covariate. Two sample $t$-tests were used for comparisons if significant effects were detected. All results were expressed as means \pm SEM and $p<0.05$ was taken to be statistically significant.

\section{Results \\ Body mass}

For the Hwameis captured in winter and summer, there were significant differences of diurnal rhythms in body masses (RM ANOVA, winter, $F_{23,192}=5.872, p<0.001$; summer, $F_{23,144}=3.090, p<0.001$, Figure 1$)$. Analysis of body mass revealed significant differences due to season and time of day (two-way ANOVA $F_{3,380}=101.424, p<$ 0.001). Mean body masses of Hwameis for each season and time of day were: winter daytime, $59.9 \pm 0.3 \mathrm{~g}(n=$ 108); winter nighttime, $57.6 \pm 0.2 \mathrm{~g}(n=108)$; summer daytime, $55.5 \pm 0.2 \mathrm{~g}(n=84)$; summer nighttime, $54.5 \pm$ 


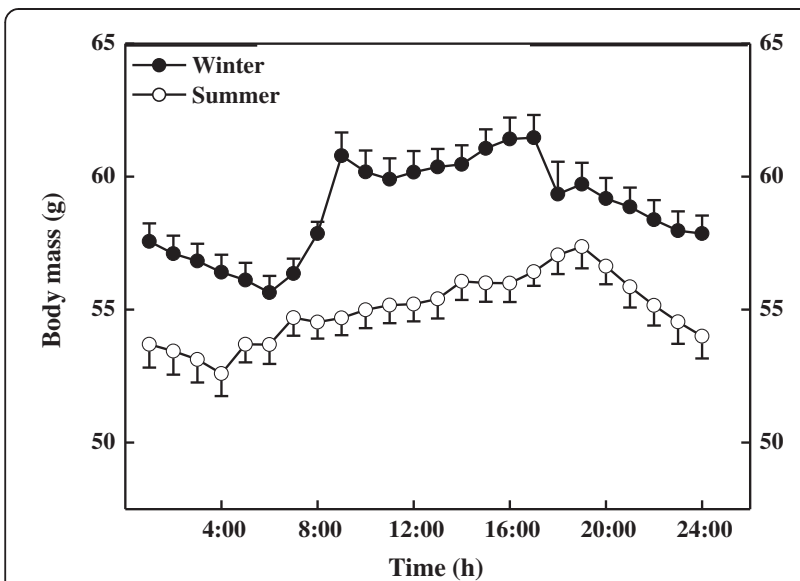

Figure 1 Body mass as a function of time of Hwameis in winter $(\boldsymbol{n}=9)$ and summer $(\boldsymbol{n}=\mathbf{7})$. Results are expressed as means \pm SEM. The light-dark cycle is indicated by the black bar lying horizontally on the graph.

$0.3 \mathrm{~g}(n=84)$ (Figure 2). The differences of body mass between daytime and nighttime birds in winter and summer was significant (post-hoc, $p<0.001$ ).

The mean body mass of winter Hwameis was $58.8 \pm$ $0.2 \mathrm{~g}(n=216)$ and that of summer birds $55.0 \pm 0.2 \mathrm{~g}(n=$ 168 ), with a significant difference between winter and summer Hwameis $\left(t_{382}=14.564, p<0.001\right)$.

\section{Body temperature}

Hwameis showed significant diurnal rhythms in body temperatures when captured in winter and summer (RM ANOVA, winter, $F_{23,192}=75.492, p<0.001 ;$ summer, $F_{23,144}=55.596, p<0.001$, Figure 3$)$. In winter, the mean body temperature was $42.5 \pm 0.1^{\circ} \mathrm{C} \quad(n=108)$ during

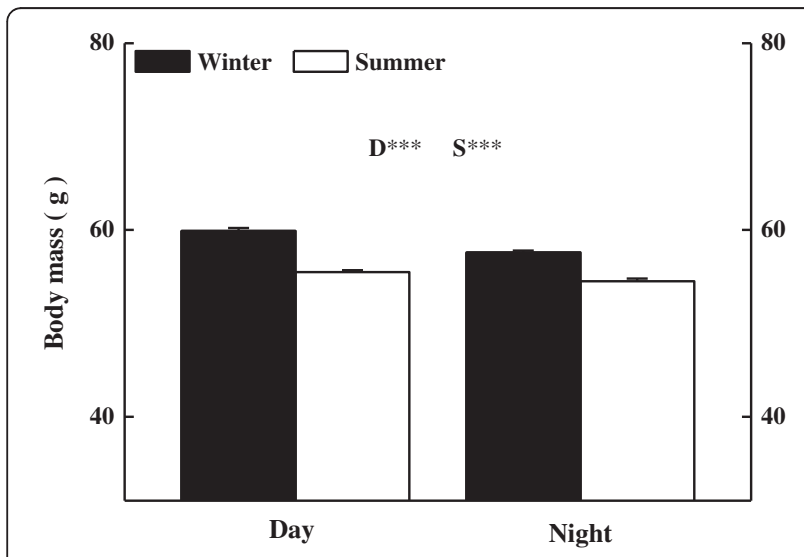

Figure 2 Mean body mass of Hwameis in daily and seasonal variation. Results are expressed as means \pm SEM. The differences in body mass were analyzed by two-way ANOVA. Body mass varied significantly with diurnal rhythm (D) and seasonal variation (S). Three asterisks indicate $p<0.001$.

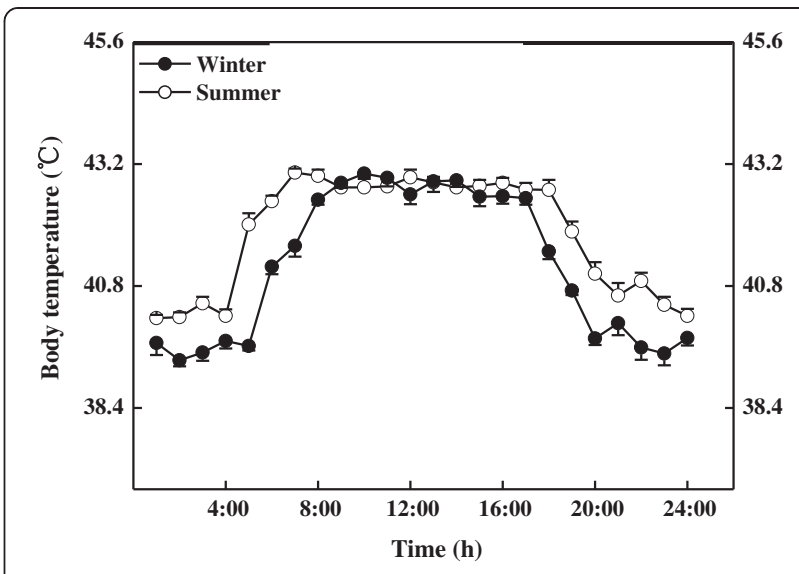

Figure 3 Body temperature as a function of time of Hwameis in winter $(\boldsymbol{n}=9)$ and summer $(\boldsymbol{n}=7)$. Results are expressed as means \pm SEM. The light-dark cycle is indicated by the black bar lying horizontally on the graph.

daytime and $39.9 \pm 0.1^{\circ} \mathrm{C} \quad(n=108)$ during nighttime tests. The mean summer body temperature was $42.8 \pm$ $0.1^{\circ} \mathrm{C}(n=84)$ for daytime birds and $40.9 \pm 0.1^{\circ} \mathrm{C}(n=84)$ for nighttime birds. Body temperatures were significantly different among groups (two-way ANOVA $F_{3,380}=$ 415.577, $p<0.001$ ) (Figure 4). For within season daily comparisons, body temperature was significantly higher in the winter daytime compared to winter nighttime and the mean body temperature in summer daytime was significantly higher than that in summer nighttime Hwameis (post-hoc, $p<0.05$ ).

The mean body temperature of winter Hwameis was $41.2 \pm 0.1^{\circ} \mathrm{C}(n=216)$ and that of summer birds $41.9 \pm$ $0.1^{\circ} \mathrm{C}(n=168)$. Winter Hwameis had a significantly

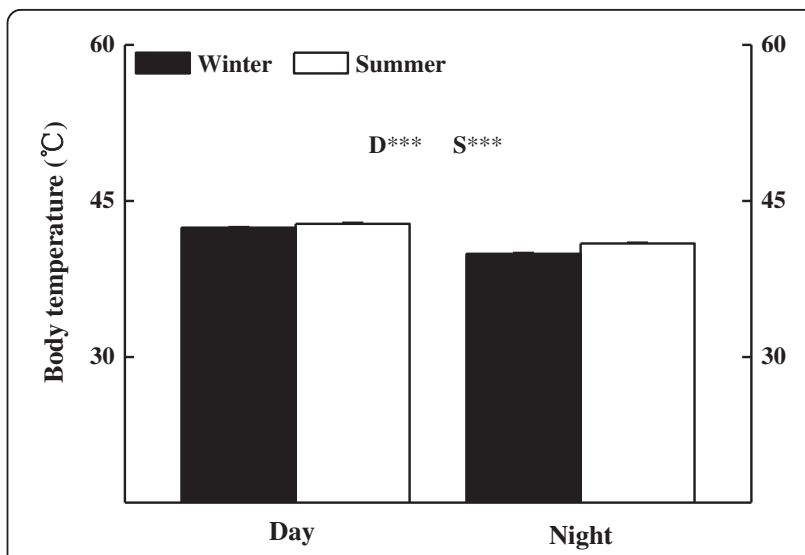

Figure 4 Mean body temperature of Hwameis in daily and seasonal variation. Results are expressed as means \pm SEM. The differences in body temperature were analyzed by two-way ANOVA. Body temperature varied significantly with diurnal rhythm (D) and seasonal variation (S). Three asterisks indicate $p<0.001$. 
lower body temperature than the summer group $\left(t_{382}=\right.$ 4.618, $p<0.001)$. However, between 9:00 and 17:00, no significant seasonal variation in body temperature was observed $\left(t_{142}=0.481, p>0.05\right.$, Figure 3$)$, with a mean body temperature of $42.8 \pm 0.1^{\circ} \mathrm{C}(n=81)$ in the winter and $42.8 \pm 0.0^{\circ} \mathrm{C}(n=64)$ in the summer.

\section{Metabolic rate}

There were significant differences in diurnal rhythms in metabolic rates of whole-organisms for the Hwameis captured in winter and summer (RM ANCOVA, winter, $F_{23,191}=12.249, p<0.001$; summer, $F_{23,143}=5.605, p<$ 0.001 , Figure 5). Mean metabolic rates of Hwameis for each season and time of day were as follows: winter daytime, $187.84 \pm 1.37 \mathrm{~mL} \mathrm{O}_{2} \cdot \mathrm{h}^{-1}(n=108)$; winter nighttime, $\quad 161.90 \pm 1.37 \quad \mathrm{~mL} \quad \mathrm{O}_{2} \cdot \mathrm{h}^{-1} \quad(n=108) ;$ summer daytime, $154.70 \pm 1.40 \quad \mathrm{~mL} \mathrm{O}_{2} \cdot \mathrm{h}^{-1} \quad(n=84)$; summer nighttime, $140.74 \pm 1.40 \mathrm{~mL} \mathrm{O}_{2} \cdot \mathrm{h}^{-1}(n=84)$ (Figure 5). Metabolic rates were significantly different among groups (two-way ANCOVA $F_{1,379}=223.865, p<0.001$ ), as well as significantly higher in winter daytime birds compared to winter nighttime birds, summer daytime birds and summer nighttime birds (post-hoc, $p<0.05$ ) (Figure 6).

The mean metabolic rate of winter Hwameis was $171.32 \pm 1.25 \mathrm{~mL} \mathrm{O}_{2} \cdot \mathrm{h}^{-1} \quad(n=216)$ and that of summer birds $152.29 \pm 1.46 \mathrm{~mL} \mathrm{O}_{2} \cdot \mathrm{h}^{-1}(n=168)$. Winter Hwameis had a significantly higher metabolic rate than the summer group (ANCOVA, $F_{1,381}=81.166, p<0.001$ ).

\section{Discussion}

Daily and seasonal changes in some environmental factors (such as temperature, photoperiod, food availability and quality) are important to animals in temperate climates and at high latitudes (Bush et al. 2008; Polo and

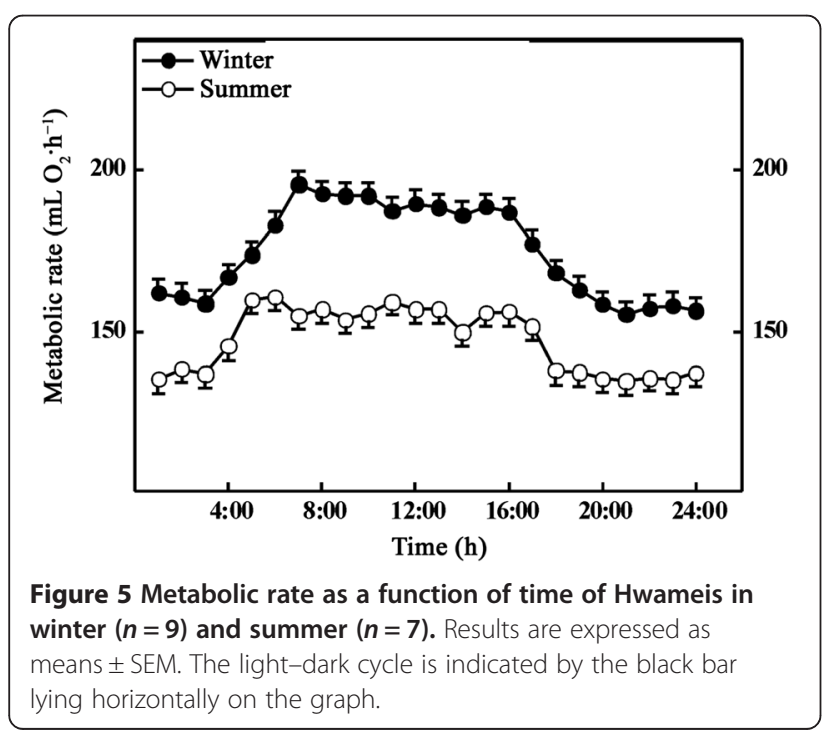

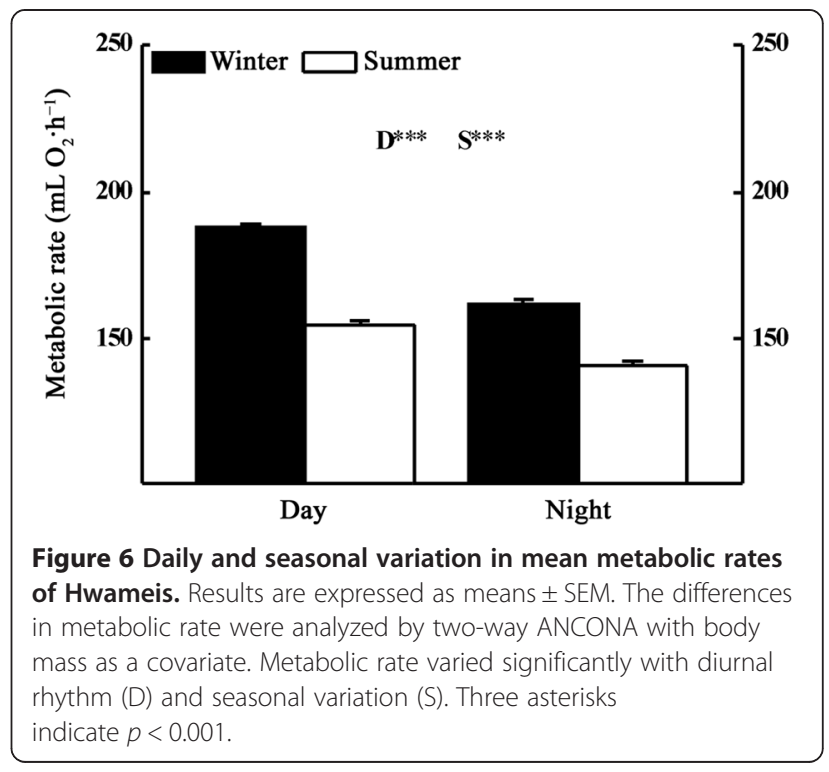

Carrascal 2008; Swanson and Merkord 2013). Small, northern and temperate habitat birds cope with daily and seasonal change through a wide array of strategies. These include, but are not limited to, adjustments in body mass, body temperature, metabolic rates and behavior (Polo and Carrascal 2008; Lindsay et al. 2009; Zheng et al. 2014a). Hwameis, maintained year round in an outside flight pen in Wenzhou, experienced average temperature differences of $22^{\circ} \mathrm{C}$ between winter and summer. Associated with these weather changes were variations in several morphological and physiological parameters related to temperature variation. Our results demonstrate that Hwameis show significant differences in body mass, body temperature and metabolic rate between diurnal rhythms and seasons.

Changes in body mass are an important adaptive strategy for many small birds and those inhabiting seasonal environments maintain a stable body mass or show an increase in body mass when exposed to winter conditions (Zheng et al. 2008b, 2014a; Swanson and Merkord 2013). Our results indicate that the Hwamei undergoes seasonal changes in body mass and is, on average, 7\% heavier in winter than in summer. This pattern is similar to that noted in a other regional species, such as the Chinese bulbul (Pycnonotus sinensis) (Zheng et al. 2008a, 2014a), other small birds in temperate zones such as the Eurasian tree sparrow (Passer montanus) (Zheng et al. 2008b) and black-capped chickadees (Poecile atricapillus) (Liknes and Swanson 2011). Our results also indicate that the Hwamei undergoes seasonal changes in body mass between day and nighttime. The mean body mass of Hwameis was significantly lower in winter mornings (3.8\% reduction) compared to summer (1.8\% reduction). This decreased second morning body 
mass of winter-acclimatized Hwameis may be due to an increased length of overnight fasting compared to summer (Lehikoinen 1987). It may also be due to reduced eating by captive Hwameis in winter relative to summer. The data on body mass of captured birds agree with that from another study of mountain chickadees (P. gambeli), which experience daily mass losses in winter of $8.3 \%$ compared to a summer reduction of $6.8 \%$ (Cooper 2007).

Birds are considered to be homeothermic endotherms, which imply the ability to maintain a constant body temperature over a broad range of ambient temperatures by adjusting their metabolism (Prinzinger et al. 1991; McKechnie and Lovegrove 2002). However, birds have a distinct diurnal cycle in body temperature with higher body temperature during the active phase than the rest phase (Nzama et al. 2010). Our results show clear seasonal variation in body temperature of Hwameis at daytime and nighttime. A significant variation indicates a higher body temperature in winter and summer birds during the daytime compared to birds during nighttime. Arens and Cooper (2005) showed that the body temperature of house sparrows was significantly higher during the daytime compared to the nighttime of the daily cycle during winter. Zungu et al. (2013) also showed that differences in body temperature of burrowing parrots (Cyanoliseus patagonus) between daytime and nighttime birds in winter and summer, were significant. Elevated body temperatures in daytime birds may be due to their enhanced state of vigilance and activity, while lower body temperatures during the night may be due to energy conservation (Cooper 2007; Zungu et al. 2013).

Many small, winter-active birds inhabiting warm and temperate latitudes in the northern hemisphere increase their BMR in winter compared to that in summer (Zheng et al. 2008a, 2014a). Our results indicate that daily and seasonal metabolic rates of Hwameis varied significantly. The metabolic rate was significantly higher in winter birds compared to summer birds and daytime birds had a significantly higher metabolic rate than nighttime birds. What factors might account for the observed seasonal pattern of change in BMR? One possibility is that, because of their size, small birds are unable to compensate for winter conditions by increasing insulation, resorting instead to enhanced thermogenesis at low ambient temperatures (Swanson 2010). Weathers and Caccamise (1978) suggested that body mass may be having an effect on seasonal adjustment of metabolic rates in birds. They also suggested that an increase in BMR is mostly beneficial for smaller $(<200 \mathrm{~g})$ birds as a result of their limited capacity in insulation and at the time were of the opinion that birds with a mass $>200 \mathrm{~g}$ should reduce their BMR in winter. However, McKechnie (2008) challenged this claim for he suggested that the data used by Weathers and Caccamise (1978) were not obtained under strict criteria for BMR. When the questionable data were removed, McKechnie (2008) found that the negative relationship between the ratio of winter to summer BMR and body mass was lost. Smit and McKechnie (2010) suggested that seasonal BMR variation in birds reveals strong correlations with latitude and winter climate variables. Zheng et al. (2014b) also found that metabolic rates of tree sparrows varied significantly with both latitude and season, with metabolic rates of Qiqihar $\left(47^{\circ} 33^{\prime} \mathrm{N}\right)$ birds higher than those of Wenzhou $\left(27^{\circ} 29^{\prime} \mathrm{N}\right)$ birds and with higher metabolic rates in winter than in summer. This suggests that habitat features are most responsible for any trend observed with regard to seasonal adjustment in BMR. With an increase of only $7 \%$ in body mass, the major response of adjustment in Hwameis during winter was not one of energy conservation. Instead, it involved an increase of $13 \%$ in the winter BMR compared with the summer rate. For Hwameis, adaptation to seasonal change has two components. In first instance, winters are colder than summers (in Wenzhou, the mean temperatures in the summer is $30^{\circ}$ and $8^{\circ} \mathrm{C}$ in the winter), hence animals that live in the winter usually increase their energy demand and energy intake (Swanson 2001; Liu and Li 2006; McKechnie et al. 2006; Vézina et al. 2006). Secondly, the quality of their diet is reduced in winter, feeding on arthropods and mollusks in the summer and eating fruits and seeds in the winter, i.e., individual birds may adjust their physiological responses in order to adapt in the environments (Karasov 2011; Wu et al. 2015). In diurnal comparisons, the metabolic response appears to be higher in daytime birds compared to nighttime birds. This is probably due to the elevated state of alertness and activity during the daytime compared to nighttime. Specific dynamic action may also contribute to elevated metabolism in birds at daytime compared to nighttime. Daytime birds that have food in their gut experience an increase in metabolic activity associated with digestion and assimilation of a meal (Arens and Cooper 2005).

\section{Conclusion}

Our results indicate that the Hwameis have a 7\% higher body mass and a 13\% higher metabolic rate in winter than in summer. This supports our previous hypothesis that the Hwamei undergoes seasonal fluctuations in body mass and metabolic rate to cope with seasonal climate change. Our results also indicate that the Hwameis have lower body mass, body temperature and metabolic rate at nighttime. These conclusions are in agreement with our hypothesis and predictions, all of which reduce nocturnal energy expenditure. The Hwameis exhibited daily and seasonal flexibility in morphology and physiology which is important under the wide environmental variation between winter and summer in Wenzhou. 


\section{Competing interests}

The authors declare that they have no competing interests.

\section{Authors' contributions}

$J \mathrm{~L}$ provided the research idea and designed the experiments. LZ, RW, YW and MW conducted the experiments and collected the data. LZ and YW finished the data analysis, compiled the results and wrote the first draft of the article. $J L$ and WZ supervised the research and revised the draft. All the authors read and approved the final manuscript.

\section{Acknowledgements}

We are grateful to Dr David L. Swanson for providing several references. We thank Dr. Ronald W. Thring for revising the English and providing suggestions. We also thank the anonymous reviewers for their numerous helpful comments and suggestions. This study was financially supported by grants from the National Natural Science Foundation of China (No. 31070366 and 31470472), the Natural Science Foundation (LY13C030005) in Zhejiang Province and the Zhejiang Province "Xinmiao" Project (2014R424032).

\section{Received: 10 November 2014 Accepted: 21 January 2015 Published online: 15 March 2015}

\section{References}

Arens JR, Cooper SJ (2005) Seasonal and diurnal variation in metabolism and ventilation in house sparrows. Condor 107:433-444

Aschoff J, Pohl H (1970) Der ruheumsatz von vögeln als funktion der tazeszeitund der körpergrösse. J Ornithol 111:38-47

Auld JR, Agrawal AA, Relyea RA (2010) Re-evaluating the costs and limits of adaptive phenotypic plasticity. Proc R Soc Lond B 277:503-511

Beldade P, Mateus ARA, Keller RA (2011) Evolution and molecular mechanisms of adaptive developmental plasticity. Mol Evol 20:1347-1363

Burns DJ, Ben-Hamo M, Bauchinger U, Pinshow B (2013) Huddling house sparrows remain euthermic at night, and conserve body mass. J Avian Biol 44:198-202

Bush NG, Brown M, Downs CT (2008) Seasonal effects on thermoregulatory responses of the Rock Kestrel, Falco rupicolis. J Ther Biol 33:404-412

Chamane SC, Downs CT (2009) Seasonal effects on metabolism and thermoregulation abilities of the Red-winged Starling (Onychognathus morio). J Ther Biol 34:337-341

Cooper SJ (2007) Daily and seasonal variation in body mass and visible fat in mountain chickadees and juniper titmice. Wilson J Ornithol 119:720-724

Doucette LI, Geiser F (2008) Seasonal variation in thermal energetics of the Australian owlet-nightjar (Aegotheles cristatus). Comp Biochem Physiol A 151:615-620

Hill RW (1972) Determination of oxygen consumption by use of the paramagnetic oxygen analyzer. J Appl Physiol 33:261-263

Karasov WH (2011) Digestive physiology: a view from molecules to ecosystem. Am J Physiol 301:R276-R284

Lehikoinen $E$ (1987) Seasonality of the daily weight cycle in wintering passerines and its consequences. Ornis Scand 18:216-226

Li SH, Li JW, Han LX, Yao CT, Shi HT, Lei FM, Yen CW (2006) Species delimitation in the Hwamei Garrulax canorus. Ibis 148:698-706

Li YG, Yang ZC, Wang DH (2010) Physiological and biochemical basis of basal metabolic rates in Brandt's voles (Lasiopodomys brandtii) and Mongolian gerbils (Meriones unguiculatus). Comp Biochem Physiol A 157:204-211

Liknes ET, Swanson DL (2011) Phenotypic flexibility of body composition associated with seasonal acclimatization in passerine birds. J Ther Bio 36:363-370

Lindsay CV, Downs CT, Brown M (2009) Physiological variation in Amethyst Sunbirds (Chalcomitra amethystina) over an altitudinal gradient in summer. J Ther Biol 34:190-199

Liu JS, Li M (2006) Phenotypic flexibility of metabolic rate and organ masses among tree sparrows Passer montanus in seasonal acclimatization. Acta Zool $\operatorname{Sin}$ 52:469-477

Liu JS, Wang DH, Sun RY (2005) Climatic adaptations in metabolism of four species of small birds in China. Acta Zool Sin 51:24-30

MacKinnon J, Phillipps K (2000) A Field Guide to the Birds of China. Oxford University Press, London

McKechnie AE (2008) Phenotypic flexibility in basal metabolic rate and the changing view of avian physiological diversity: a review. J Comp Physiol B 178:235-247
McKechnie AE, Lovegrove BG (2002) Avian facultative hypothermic responses: a review. Condor 104:705-724

McKechnie AE, Wolf BO (2004) The allometry of avian basal metabolic rate: good predictions need good data. Physiol Biochem Zool 77:502-521

McKechnie AE, Freckleton RP, Jetz W (2006) Phenotypic plasticity in the scaling of avian basal metabolic rate. Proc R Soc Lond B 273:931-937

McNab BK (2006) The relationship among flow rate, chamber volume and calculated rate of metabolism in vertebrate respirometry. Comp Biochem Physiol A 145:287-294

McNab BK (2009) Ecological factors affect the level and scaling of avian BMR. Comp Biochem Physiol A 152:22-45

Nzama SN, Downs CT, Brown M (2010) Seasonal variation in the metabolismtemperature relation of House Sparrows (Passer domesticus) in KwaZulu-Natal, South Africa. J Ther Biol 35:100-104

Petit M, Lewden A, Vézina F (2014) How dose flexlibility in body mass composition relate to seasonal changes in metabolic performance in a small passerine wintering at northern latitude? Physiol Biochem Zool 87:539-549

Piersma T, Drent J (2003) Phenotypic flexibility and the evolution of organismal design. Trends Ecol Evol 18:228-233

Pohl H, West GC (1973) Daily and seasonal variation in metabolic response to cold during rest and exercise in the common redpoll. Comp Biochem Physiol A 45:851-867

Polo V, Carrascal LM (2008) Nocturnal body mass loss in coal tits Periparus ater: the combined effects of ambient temperature and body reserves. Acta Zool $\operatorname{Sin}$ 54:615-621

Prinzinger R, Prebmar A, Schleucher E (1991) Body temperature in Birds. Comp Biochem Physiol A 99:499-506

Schmidt-Nielsen K (1997) Animal Physiology: Adaptation and Environment. Cambridge University Press, London

Smit B, McKechnie AE (2010) Avian seasonal metabolic variation in a subtropical desert: basal metabolic rates are lower in winter than in summer. Funct Eco 24:330-339

Starck JM (2009) Phenotypic plasticity, cellular dynamics, and epithelial turnover of the intestine of Japanese quail (Coturnix coturnix japonica). J Zool 238:53-79

Swanson DL (1990) Seasonal variation in cold hardiness and peak rates of coldinduced thermogenesis in the dark-eyed junco, Junco hyemalis. Auk 107:561-566

Swanson DL (2001) Are summit metabolism and thermogenic endurance correlated in winter- acclimatized passerine birds? J Comp Physiol B 171:475-481

Swanson DL (2010) Seasonal metabolic variation in birds: functional and mechanistic correlates. In: Thompson CF (ed) Current Ornithology. Springer, Berlin, pp 75-129

Swanson DL, Merkord C (2013) Seasonal phenotypic flexibility of flight muscle size in small birds: a comparison of ultrasonography and tissue mass measurements. J Ornithol 154:119-127

Swanson DL, Zhang YF, Liu JS, Merkord CL, King MO (2014) Relative roles of temperature and photoperiod as drivers of metabolic flexibility in dark-eyed juncos. J Exp Biol 217:866-875

Vézina F, Jalvingh K, Dekinga A, Piersma T (2006) Acclimation to different thermal conditions in a northerly wintering shorebird is driven by body mass-related changes in organ size. J Exp Biol 209:3141-3154

Weathers WW, Caccamise F (1978) Seasonal acclimatization to temperature in monk parakeets. Oecologia 35:173-183

Wiersma P, Muñoz-Garcia A, Walker A, Williams JB (2007) Tropical birds have a slow pace of life. Proc Natl Acad Sci 104:9340-9345

Wikelski M, Spinney L, Schelsky W, Scheuerlein A, Gwinner E (2003) Slow pace of life in tropical sedentary birds: a common-garden experiment on four stonechat populations from different latitudes. Proc R Soc Lond B 270:2383-2388

Wu MS, Xiao YC, Yang F, Zhou LM, Zheng WH, Liu JS (2014) Seasonal variation in body mass and energy budget in Chinese bulbuls (Pycnonotus sinensis). Avian Res 5:4

Wu MX, Zhou LM, Zhao LD, Zhao ZJ, Zheng WH, Liu JS (2015) Seasonal variation in body mass, body temperature and thermogenesis in the Hwamei, Garrulax canorus. Comp Biochem Physiol A 179:113-119

Xia SS, Yu AW, Zhao LD, Zhang HY, Zheng WH, Liu JS (2013) Metabolic thermogenesis and evaporative water loss in the Huamei Garrulax canorus. J Therm Biol 38:576-581

Yuni LPEK, Rose RW (2005) Metabolism of winter-acclimatized New Holland honeyeaters Phylidonyris novaehollandiae from Hobart, Tasmania. Acta Zool $\sin 51: 338-343$ 
Zheng GM, Zhang CZ (2002) Birds in China. China Forestry Publishing House, Beijing

Zheng WH, Li M, Liu JS, Shao SL (2008a) Seasonal acclimatization of metabolism in Eurasian tree sparrows (Passer montanus). Comp Biochem Physiol A 151:519-525

Zheng WH, Liu JS, Jang XH, Fang YY, Zhang GK (2008b) Seasonal variation on metabolism and thermoregulation in Chinese bulbul. J Therm Biol 33:315-319

Zheng WH, Lin L, Liu JS, Pan H, Cao MT, Hu YL (2013a) Physiological and biochemical thermoregulatory responses of Chinese bulbuls Pycnonotus sinensis to warm temperature: Phenotypic flexibility in a small passerine. J Therm Biol 38:483-490

Zheng WH, Lin L, Liu JS, Xu XJ, Li M (2013b) Geographic variation in basal thermogenesis in little buntings: Relationship to cellular thermogenesis and thyroid hormone concentrations. Comp Biochem Physiol A 164:240-246

Zheng WH, Li M, Liu JS, Shao SL, Xu XJ (2014a) Seasonal variation of metabolic thermogenesis in Eurasian tree sparrows Passer montanus over a latitudinal gradient. Physiol Biochem Zool 87:704-718

Zheng WH, Liu JS, Swanson DL (2014b) Seasonal phenotypic flexibility of body mass, organ masses, and tissue oxidative capacity and their relationship to RMR in Chinese bulbuls. Physiol Biochem Zool 87:432-444

Zungu MM, Brown M, Downs CT (2013) Seasonal thermoregulation in the burrowing parrot (Cyanoliseus patagonus). J Therm Biol 38:47-54

\section{Submit your next manuscript to BioMed Central and take full advantage of:}

- Convenient online submission

- Thorough peer review

- No space constraints or color figure charges

- Immediate publication on acceptance

- Inclusion in PubMed, CAS, Scopus and Google Scholar

- Research which is freely available for redistribution 